\title{
Utilization of Cheese Whey and UF Milk Permeate in Manufacture of Egyptian Baladi Bread
}

\author{
El-Batawy, O.I., Samar M. Mahdy \& M.Y. Abo El-Naga \\ Food Science Dept.,Fac. of Agric., Ain Shams Univ., Shoubra Khaima, 11241, Cairo, Egypt. \\ Received: 2 January, 2018 \\ Revised: 7 March, 2018 \\ Accepted: 18 March, 2018
}

\begin{abstract}
The effect of substituting water (50 and $100 \%$ ) with cheese whey (CW) and UF milk permeate (UFMP) as the by-product of some dairy industries on the quality of Egyptian Baladi bread were investigated. Changes in the physical, chemical and organoleptic properties of bread products were determined. Substituting the water by either whey or permeate in Baladi bread manufacture caused significant effect on dough mixing properties (Farinograph) and slight increase in ratio of solution absorption for the dough preparation. A significant $(\mathrm{P}<0.05)$ increase was observed in the values of mixing tolerance index (MTI) for permeate dough at two substitution levels. The values of energy, extensibility, resistance of extension and proportion number increased significantly $(\mathrm{P}<0.05)$ in both whey or permeate dough by increasing replacing level. Whey or permeate had significant effects on texture profile analysis of Baladi bread. Total solids, protein, ash, carbohydrate and minerals contents were faound to increase significantly $(\mathrm{P}<0.05)$ in resultant bread with increasing the ratio of whey or permeate added to the bread blend. The values of alkaline water retention capacity for all tested bread samples were reduced significantly $(\mathrm{P}<0.05)$ during storage. Substitution of water with whey or permeate in Baladi bread formula especially $100 \%$ could be enhance the sensory properties in the resultant product. It could be concluded that, Egyptian Baladi bread can made by adding cheese whey or milk permeate as a water substitute up to $100 \%$. This fortification could enhance the quality attributes, acceptability and nutritive value of the product.
\end{abstract}

Key words: Baladi bread, cheese whey, milk permeate, cheese by-product

\section{INTRODUCTION}

Bread is one of the most widely consumed food product in the world. It is a staple diet that is consumed daily, and its quality especially sensory attributes are highly considered by consumers (Motrena et al., 2011). In Egypt, as well as the Middle East, Baladi bread is the Egyptian type of Arabic bread, which is the main staple in the Middle Eastern diet. Baladi (means traditional) bread production is subsidized by the Egyptian ministry of supply. Baladi bread is circular loaf $(1 \mathrm{~cm}$ thickness, 10 to $30 \mathrm{~cm}$ diameter) consisting of two layers. It is commonly prepared from high extraction flour (82\%) with protein content between 10 and $12 \%$, and made by a straight dough method. Baladi bread dough is soft $(70-75 \%$ moisture), fermented for $2 \mathrm{hr}$ and baked at a substantially higher temperature $\left(400-500^{\circ} \mathrm{C}\right)$ for $1-2 \mathrm{~min}$ (Mousa et al., 1979). Cheese manufacturing results in the generation of abundant quantities of whey as a by product, and this must be disposed of or processed to avoid biological load of the environment. Each Kilogram of produced hard cheese generates, in average, 9 liters of whey (Jelen \& Tossavainen
2003, Onwulata \& Huth 2008). World production of milk whey is estimated at 180 to $190 \times 10^{6}$ tones/ year, with an yearly increase rate of $1-2 \%$, but only around $50 \%$ is processed (Baldasso et al., 2011, Román et al., 2012). The whey could be used directly in liquid form $(50 \%$ ), while $30 \%$ was processed to powder cheese whey and $15 \%$ were used for the production of lactose product composed of $74 \%$ sugars (as lactose), 8\% minerals and 3\% fat (Morr, 1989, Spalatelu, 2012). Cheese whey represents a serious pollutant in waste water of dairy industry because of its high organic load from one side and also for the large volume generated, from other side. According to Metcalf \& Eddy (2003) as well as Carvalho et al. (2013) the biological oxygen demand of cheese whey is in the range $27-60 \mathrm{~g} \mathrm{~L}^{-1}$ and a chemical oxygen demand in the interval 50-102 $\mathrm{g} \mathrm{L}^{-1}$. Therefore, Whey is considered as potential ingredients for enhancing nutritive value and organoleptic characteristics of many food products including bread and other bakery products (Riera-Rodriguez, 2002, Drokan et al., 2003, Jooyandeh, 2006, Rantamaki et al., 2006, Jooyandeh et. al., 2009). Hassan et al. (2013) report- 
ed that use of cheese whey in French and pan bread manufacture resulted in breads with more nutritional value, richer in flavour and taster compared to the standard white wheat bread.

Ultrafiltration of milk produces a surplus quantity of permeate as by-product. It contains lactose sugar as the major constituent beside water soluble vitamins and salts of milk. Therefore, permeate can be considered as an ingredient with nutritious significance. Permeate is a subject of environmental concern due to its high biological oxygen demand (Murad et al., 2011, Marhamatizadeh et al., 2012, Khider et al., 2015). A number of treatments for whey-permeate have been developed in an effort to overcome the problem of its disposal. Permeate could be used as an ingredient to existing types of food supplements used for the formulations of diets for malnourished children. Permeate can offer many benefits for backed products such as enhancing crust browning causing not only improvement of appearance but also cause a pleasant caramelized flavour, enhance moisture retention and creation of a tender crumb structure. On the other side, lactose content assist permeates ability to improve the texture of baked products, and positively affect their appearance and colour. Also, permeate is a good source for soluble salts such as calcium, potassium, sodium, phosphorus and magnesium in baked products (Marhamatizadeh et al., 2012, Udovicic et al., 2013). Whey and permeate represent 80 to $90 \%$ of the volume of the milk used for cheese processing. They contain about $50 \%$ of the total solids present in the original whole milk, including $20 \%$ of protein for cheese whey, and most of lactose, mineral and water-soluble vitamins (Marshall et. al., 1982, Renner \& Abd El-Salam,1991).

The present study aimed to develop a suitable technology for utilization of whey and permeates in Baladi bread manufacture not only to enhance its nutritive value, but also to help in solving the problems of whey disposal at industry level. Therefore, cheese whey and milk permeate were used as water substitute of Egyptian Baladi bread, and investigating their effect on the quality of the product.

\section{MATERIALS AND METHODS}

\section{Materials}

Sweet cheese whey (from Mozzarella cheese manufacturing) and ultrafiltration milk permeate (UFMP) were obtained from Snow White CO., El-
Domty $6^{\text {th }}$ October City, Second Industrial region, Egypt. Permeate was a by-product from the ultrafiltration of cow's skim milk at $50^{\circ} \mathrm{C}$ using spiralwound module membrane supplied by APV Pasilac, Denmark. The whey and permeate were first pasteurized at $85^{\circ} \mathrm{C} / 10 \mathrm{~min}$, cooled and kept frozen at $-20^{\circ} \mathrm{C}$ until use. Wheat flour (WF) with extraction rate $82 \%$ was obtained from the North Cairo Flour Mills Company, Egypt. The wheat flour was found to contain $88.45,11.02,2.98,0.96$ and $0.761 \%$ total solids, protein, crude fiber, fat and ash contents, respectively. Sugar, salt and dried yeast were purchased from a local market in Egypt.

\section{Methods:}

\section{Technological method:}

\section{Baladi bread preparation:}

Baladi bread was prepared by mixing each 100 $\mathrm{g}$ of wheat flour (82\% extraction) with $0.5 \mathrm{~g}$ of active dry yeast, $1.5 \mathrm{~g}$ of salt, $1 \mathrm{~g}$ sugar, $65-70 \mathrm{ml}$ water, (substituted with whey or permeate at 0,50 and $100 \%$ levels) by hand for about $10 \mathrm{~min}$ to form the needed dough. The dough was left to ferment for $1 \mathrm{hr}$ at $30^{\circ} \mathrm{C}$ and $85 \%$ relative humidity, and was then divided into $125 \mathrm{~g}$ pieces. The pieces were arranged on a wooden board that had been sprinkled with a fine layer of bran and were left to ferment for about $45 \mathrm{~min}$ at the same temperature and relative humidity. The pieces of fermented dough were flattened to be about $20-\mathrm{cm}$ in diameter, proofed at $30-35^{\circ} \mathrm{C}$ and $85 \%$ relative humidity for $15 \mathrm{~min}$ and then were baked at $300-350^{\circ} \mathrm{C}$ for $1-2 \mathrm{~min}$. The loaves were allowed to cool at room temperature for $1 \mathrm{hr}$ before being packed in polyethylene bags and stored in an incubator at $25^{\circ} \mathrm{C}$ for further analysis. All the test breads were stored for 5 days at room temperature and checked for the growth of mould.

\section{Analytic methods:}

Moisture, protein, ash and crude fiber contents of the raw materials and bread samples were determined as the method described in the AOAC (2012). Fat and titratable acidity (TA) contents for whey and permeate samples were determined as given by Ling, (1963). The $\mathrm{pH}$ values were measured in whey and permeate samples using lad $\mathrm{pH}$ meter with a glass electrode (Hanna model 8417 digital $\mathrm{pH}$ meter). All analyses were carried out in triplicate. Minerals content of bread samples were determined by Atomic Absorption Spectrophotometer (model, Ciba Corning Diagnostics Scientific Instruments Essex, England) according to the pro- 
cedure outlined by the AOAC (2012).

\section{Dough characteristics:}

Dough mixing properties (Water absorption, dough development time, dough stability and mixing tolerance index (MIT) were determined by Farinograph (Model Type No: 860703, Brabender OHG, Duisburg, Germany) according to the standard methods o the AACC (2000). The elastic properties of dough (dough energy, extensibility, dough resistance to extension and proportion number) were measured using Extensograph (Model Type No: 860703, Brabender OHG, Duisburg, Germany) according to the standard of the AACC (2000) methods.

\section{Bread properties:}

\section{Texture profile analysis (TPA):}

The instrumental texture measurements were made on fresh and stored bread samples with a Universal testing machine (TMS-Pro, Stable Micro System USA), provided with software as described by Davidou et al. (1996). One $\mathrm{cm}$ of the edges of the bread samples was removed from all loaves. Approximately $(40 \times 40 \times 30) \mathrm{mm}$ piece was punched out, placed on the flat stage and the texture was determined. Texture profile analysis (TPA) was performed with a light weight clear perspex cylindrical probe (25 $\mathrm{mm}$ in diameter). Bread slices were compressed to $50 \%$ of their original height at a deformation speed of $1 \mathrm{~mm} / \mathrm{s}$ and the curves of the compression were recorded. The software was used to calculate firmness $(\mathrm{N})$, cohesiveness, gumminess $(\mathrm{N})$, chewiness $(\mathrm{N})$, springiness and resilience values of the bread samples. Means of six replicates and standard deviations for TPA parameters were calculated and used for correlation analysis.

\section{Alkaline water retention capacity (AWRC):}

Freshness of Baladi bread was determined using Alkaline Water Retention Capacity test (AWRC) according to the method of Yamazaki (1953), modified by Kitterman \& Rubenthaler (1971) after wrapping in polyethylene bags and storage at room temperature for 1, 2 and 3 days.

\section{Sensory evaluation:}

The loaves of bread were allowed to cool on racks for about $1 \mathrm{hr}$ then evaluated organoleptically for general appearance, surface colour of crust, taste, odour, roundness, crumb distribution, separation layer, upper layer thickness and lower layer thickness by 10 trained panelists according to El-Farra et al. (1982).

\section{Statistical analysis:}

Statistical analysis was performed according to SAS Institute (1999) using General Linear Model (GLM) with main effect of treatments. Duncan's multiple range tests was used to separate among of three replicates at $P \leq 0.05$.

\section{RESULTS AND DISCUSSION}

\section{physiochemical properties of cheese whey and UF milk permeate:}

As shown in Table (1), significant differences could be observed in most physiochemical properties between cheese whey and UF milk permeate. Total solids, fat, protein and titrable acidity contents were significantly higher in cheese whey compared with milk permeate. While, carbohydrate content and $\mathrm{pH}$ value of cheese whey were significantly lower compared with UF milk permeate. No significant difference was observed in ash content between cheese whey and UF milk permeate. These results are in agreement with Morr (1989), who reported that, cheese whey contains about $7 \%$ total solids comprising of about 10-12\% proteins, 74\% lactose, $8 \%$ minerals and 3\% fat. The differences in the physiochemical properties between cheese whey and UF milk permeate may cause various effects on the properties of Baladi bread fortified with whey or permeate.

\section{Dough characteristics:}

Rheological characteristics reflect the dough properties during processing and the quality of final product. Data in Table (2) and Fig (1) show Farinograph evaluations of wheat flour dough made by

Table 1: Some chemical composition and pH value of cheese whey and UF milk permeate.

\begin{tabular}{lccccccc}
\hline Character assessed & T.S (\%) & Fat (\%) & Protein (\%) & Ash (\%) & Carbohydrate (\%) & Acidity (\%) & pH value \\
\hline Whey & $7.15^{\mathrm{a}}$ & 0.8 & $0.94^{\mathrm{a}}$ & $0.46^{\mathrm{a}}$ & $5.11^{\mathrm{b}}$ & $0.32^{\mathrm{a}}$ & $5.20^{\mathrm{b}}$ \\
Permeate & $6.51^{\mathrm{b}}$ & $-*$ & $0.14^{\mathrm{b}}$ & $0.50^{\mathrm{a}}$ & $6.20^{\mathrm{a}}$ & $0.15^{\mathrm{b}}$ & $6.54^{\mathrm{a}}$ \\
\hline
\end{tabular}

*: Not determined

$\mathrm{a}, \mathrm{b}, \mathrm{c}$ : Means with same letter among treatments are not significantly different at $P \leq 0.05$. 
replacing water with different ratios of whey and permeate. The CW and UFMP slightly increased percentage of water absorption, the highest increase was observed in dough prepared with 100\% permeate, which reached $58 \%$ compared to $56 \%$ for control dough (100\% water). It is known that most dairy proteins are water soluble but gluten, the wheat dough protein, is mostly water insoluble (Hallen et al., 2004 and Anton et al., 2008).

Erdogdu-Arnoczky (1996) observed that dairy ingredients including whey powder increased water absorption. Also, Al-Eid et. al., (1999) reported that dough prepared by the $100 \%$ of unfermented or $25 \%$ of fermented permeate has significantly higher water absorption. Also, Gélinas et. al., (1995) found that fermented milk gave a significantly higher dough water absorption compared to the non-fermented milk. The higher water absorption of dough samples may be due to the increased hydration capacity of whey and permeate. This increase could be attributed to the water-soluble components of whey and permeate such as lactose, albumins and globulins (Bilgin et al., 2006).

Erdogdu-Arnoczky (1996) found that bread dough prepared with acid whey powder required $1 \%$ more water than did the control when heated at $80^{\circ} \mathrm{C}$. However, no changes were observed in both arrival time and dough development time by replacing water by either cheese whey or UF milk permeate. Arrival time and dough development time were 1.5 and $2.0 \mathrm{~min}$ for all samples.Dough stability is an indicator of dough strength. Replacing mixing water by $50 \%$ cheese whey has no effect on dough stability (6 min). These results agree with Hassan et al., (2013) who found no significant effect in stability of dough with $50 \%$ acid cheese whey. On the other side, replacing by $50 \%$ UF milk permeate and $100 \%$ cheese whey showed slight increase (6.5 min). This is in contrary with Hassan et al. (2013) who reported a decrement in dough stability value of pan bread with up to $75 \%$ acid cheese whey. Gélians et al. (1995) reported that highly acid dairy dough stability showed a decrement in their values as ingredients significantly reduced dough mixing stability. While, dough prepared by $100 \%$ UF milk permeate has significantly $(P<0.05)$ higher dough stability $7.5 \mathrm{~min}$ compared with the control which recorded $6 \mathrm{~min}$. this could be attributed to the higher content of lactose in UF milk permeate.

These results have been confirmed with Bilgin et al., (2006) who found that, the addition of whey and buttermilk significantly increased dough stability, due to the role of physico-chemical characteristics of whey and buttermilk which contain different protein sources, milk fat and lactose. Al-Eid et al. (1999) found that the substitution water with unfermented permeate up to $100 \%$ and fermented permeate up to $50 \%$ increased Farinograph stability time and that was associated with a significant increase in dough mixing tolerance. Greater effects were observed on the mixing tolerance index values (MTI) for permeate dough at 50 and 100\% substitute, which decreased significantly $(P<0.05)$ to 30 and $20 \mathrm{BU}$, respectively compared to $50 \mathrm{BU}$ for control. On the other side, the whey dough showed similar MTI to the control. Volpe \& Zabik (1975) postulated that interaction between $\kappa$-casein and $\beta$-lactoglobulin with dough proteins caused the mixing tolerance to be reduced.

Extensibility is a measure for the ability of the dough to increase its volume by the gas produced from yeast during proofing. Excessively high ex-

Table 2: Effect of substituting water with cheese whey or UF milk permeate on dough mixing properties (Farinograph) of Baladi bread made of flour with $82 \%$ extraction rate

\begin{tabular}{|c|c|c|c|c|c|}
\hline \multirow{3}{*}{ Characteristics } & \multicolumn{5}{|c|}{ Treatments } \\
\hline & \multirow{2}{*}{$\frac{\text { Water }}{100 \%}$} & \multicolumn{2}{|c|}{ Permeate } & \multicolumn{2}{|c|}{ Whey } \\
\hline & & $50 \%$ & $100 \%$ & $50 \%$ & $100 \%$ \\
\hline Water absorption (\%) & $56^{\mathrm{a}}$ & $57^{\mathrm{a}}$ & $58^{\mathrm{a}}$ & $57 \mathrm{a}$ & $57^{\mathrm{a}}$ \\
\hline Arrival time (min) & $1.5^{\mathrm{a}}$ & $1.5^{\mathrm{a}}$ & $1.5^{\mathrm{a}}$ & $1.5^{\mathrm{a}}$ & $1.5^{\mathrm{a}}$ \\
\hline Dough development time (min) & $2.0^{\mathrm{a}}$ & $2.0^{\mathrm{a}}$ & $2.0^{\mathrm{a}}$ & $2.0^{\mathrm{a}}$ & $2.0^{\mathrm{a}}$ \\
\hline Dough stability (min) & $6^{\mathrm{b}}$ & $6.5^{b}$ & $7.5^{\mathrm{a}}$ & $6^{\mathrm{b}}$ & $6.5^{\mathrm{b}}$ \\
\hline Departure time (min) & $7.0^{\mathrm{d}}$ & $8.0^{\mathrm{b}}$ & $9^{a}$ & $7.0^{\mathrm{d}}$ & $7.5^{\mathrm{c}}$ \\
\hline Mixing tolerance index MTI (BU) & $50^{\mathrm{a}}$ & $30^{\mathrm{b}}$ & $20^{c}$ & $50^{\mathrm{a}}$ & $50^{\mathrm{a}}$ \\
\hline
\end{tabular}

a, b, c: Means with the same letter among treatments are not significantly different at $\mathrm{P} \leq 0.05$. 


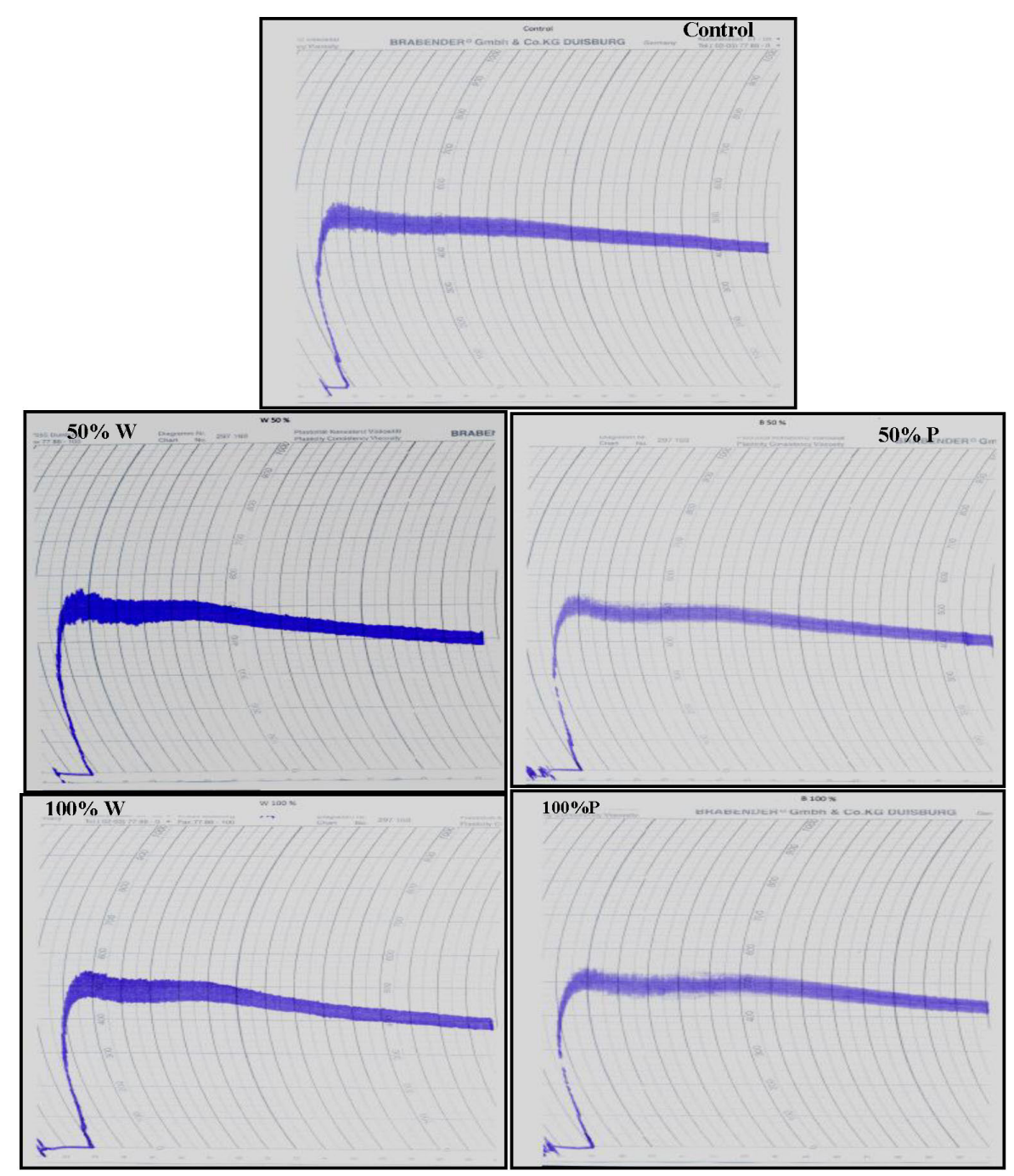

Fig. 1: Farinogram for dough samples affected by water replacing with cheese whey (W) or UF milk permeate $(P)$ at different levels

tensibility causes weakening and slacking of dough collapsing during proofing or baking in the oven. The maximum values for extension resistance of the formed dough are an indicator for the gas retention during proofing as well as an indicator for the springiness of the produced bread. High values of extension resistance lead to reduction in loaf volume due to the inability of the dough to come to the optimum height caused by the gas produced during proofing and yeast activity (Sharadanant \& Khan, 2003, Hassan et. al., 2013). There is general agreement about the link between testing and baking performance.

A good loaf volume is obtained if the gas bubbles in the fermented dough expand with minimal rupturing of gluten net during proofing and baking. Therefore, baking performance is related to the interplay between resistance to extension (Rmax) and extensibility (E) (Anderssen et al., 2004). Exten- sograph results for the investigated dough samples are shown in Table (3). The values of energy and extensibility $(\mathrm{E})$ increased significantly $(P<0.05)$ in both whey or permeate dough by increasing replacing level. The highest values of energy and extensibility were $112 \mathrm{~cm}^{3}$ and $148 \mathrm{~mm}$, respectively for dough with $100 \%$ permeate compared to $65 \mathrm{~cm}^{3}$ and $128 \mathrm{~mm}$ for control (100\% water). On the other side, the values of resistance to extension $(\mathrm{R})$ and proportion number increased significantly $(P<0.05)$ by increasing whey and permeate replacement level. The highest increase was observed in permeate dough at $100 \%$ which recorded $444 \mathrm{BU}$ and 4 for resistance to extension $(\mathrm{R})$ and proportion number, respectively compared to $319 \mathrm{BU}$ and 2.5 for control. It is clear that, use of dairy ingredients improves the handling properties of bread dough, as well as the bread quality. 
Table 3: Effect of substituting water with cheese whey or UF milk permeate on extensograph properties

\begin{tabular}{lccccc}
\hline \multirow{2}{*}{ Characteristics } & \multicolumn{4}{c}{ Treatments } \\
\cline { 2 - 6 } & Water & \multicolumn{2}{c}{ Permeate } & \multicolumn{2}{c}{ Whey } \\
\cline { 2 - 6 } & $\mathbf{1 0 0 \%}$ & $\mathbf{5 0 \%}$ & $\mathbf{1 0 0 \%}$ & $\mathbf{5 0 \%}$ & $\mathbf{1 0 0 \%}$ \\
\hline Dough energy $\left(\mathrm{cm}^{2}\right)$ & $65^{\mathrm{cd}}$ & $78^{\mathrm{b}}$ & $112^{\mathrm{a}}$ & $54^{\mathrm{d}}$ & $70 \mathrm{~b}^{\mathrm{c}}$ \\
Dough extensibility (E) (mm) & $128^{\mathrm{b}}$ & $146^{\mathrm{a}}$ & $148^{\mathrm{a}}$ & $133^{\mathrm{a}}$ & $145^{\mathrm{a}}$ \\
Dough resistance to extension $(\mathrm{R})(\mathrm{BU})$ & $319^{\mathrm{b}}$ & $312^{\mathrm{b}}$ & $444^{\mathrm{a}}$ & $258^{\mathrm{c}}$ & $284^{\mathrm{bc}}$ \\
Proportion number $(\mathrm{D}=\mathrm{R} / \mathrm{E})$ & $2.5^{\mathrm{b}}$ & $2.7^{\mathrm{b}}$ & $4.0^{\mathrm{a}}$ & $2.2^{\mathrm{b}}$ & $2.4^{\mathrm{b}}$ \\
\hline
\end{tabular}

a, b, c: Means with the same letter among treatments are not significantly different at $P \leq 0.05$.

However, the complexity of the bread making system, including several stages of processing and interaction among the components, make it difficult to predict the performance of a particular dairy product (Erdogdu-Arnoczky et al., 1996).

\section{Bread characteristics:}

\section{Chemical composition}

Chemical compositions of Baladi bread containing different ratios of CW or UFMP are presented in Table (4). Substitution water by $\mathrm{CW}$ or UF milk permeate in preparing Baladi bread significantly increased the dry matter content in resulting product. This increase in dry matter content of bread correlated to the lactose, protein and ash content in cheese whey or UF milk permeate. These results agree with that reported by Khider et. al., (2015) who showed that, supplementation of pan bread with fermented permeate increased the dry matter content in final product. Replacement of water in Baladi bread formulas with cheese whey or UF milk permeate had no significant effect in crude fiber content among all treatments. This is may be due to that, cheese whey or UF milk per- meate don't contain crude fiber. A slight difference was observed in protein and fat of different Baladi bread samples.

Ash content was fount to increase significantly $(P \leq 0.05)$ with increasing the ratios of whey or permeate in the bread blend. This increase may be due to the higher ash content in whey and permeate. Rizk (2016) reported that, milk permeate contains electrolytes-sodium, potassium, magnesium, zinc and calcium that could be utilized in different food products. Also, Fitzpatrick et al. (2001) stated that, milk permeate is rich in minerals and fortification the food product with permeate enhances the overall nutritional content of a food product. Utilization of cheese whey or UF milk permeate as water substitute in Baladi bread dough formula caused a significant increase in carbohydrate content of the resultant product, and this could be due to the higher lactose content in cheese whey or UF milk permeate (Table 1). Our results agree with Divya \& Rao (2010), Hassan et. al. (2013) and Khider et. al. (2015), who found that, fat, ash and protein contents increased directly proportional to the ratios of some dairy ingredients such as acid

Table 4: Effect of substituting water with cheese whey or UF milk permeate on chemical composition of Egyptian Baladi bread

\begin{tabular}{llllll}
\hline & \multicolumn{5}{c}{ Treatments } \\
\cline { 2 - 5 } \multicolumn{1}{c}{ Parameter } & Water & \multicolumn{2}{c}{ Permeate } & \multicolumn{2}{c}{ Whey } \\
\cline { 2 - 6 } & $\mathbf{1 0 0 \%}$ & $\mathbf{5 0 \%}$ & $\mathbf{1 0 0 \%}$ & $\mathbf{5 0 \%}$ & $\mathbf{1 0 0 \%}$ \\
\hline Dry matters (\%) & $60.90^{\mathrm{b}}$ & $62.18^{\mathrm{a}}$ & $62.87^{\mathrm{a}}$ & $63.57^{\mathrm{a}}$ & $63.69^{\mathrm{a}}$ \\
Protein (\%) & $7.32^{\mathrm{c}}$ & $7.61^{\mathrm{b}}$ & $7.68^{\mathrm{b}}$ & $7.93^{\mathrm{a}}$ & $8.22^{\mathrm{a}}$ \\
Crude fiber (\%) & $1.61^{\mathrm{a}}$ & $1.60^{\mathrm{a}}$ & $1.60^{\mathrm{a}}$ & $1.62^{\mathrm{a}}$ & $1.59^{\mathrm{a}}$ \\
Crude fat (\%) & $1.10^{\mathrm{b}}$ & $1.39^{\mathrm{b}}$ & $1.50^{\mathrm{b}}$ & $1.65^{\mathrm{b}}$ & $1.91^{\mathrm{a}}$ \\
Crude ash (\%) & $1.856^{\mathrm{c}}$ & $2.143^{\mathrm{b}}$ & $2.641^{\mathrm{a}}$ & $2.295^{\mathrm{b}}$ & $2.634^{\mathrm{a}}$ \\
Carbohydrate (\%) & $48.43^{\mathrm{c}}$ & $50.62^{\mathrm{b}}$ & $52.82^{\mathrm{a}}$ & $50.54^{\mathrm{b}}$ & $51.91^{\mathrm{a}}$ \\
\hline
\end{tabular}

a, b, c: Means with the same letter among treatments are not significantly different at $P \leq 0.05$. 
cheese whey added in the formulation of pan bread. Therefore, it could be stated that, replacement the water in Baladi bread formula with milk permeate or cheese whey improves the nutritive value of the resulting bread.

\section{Mineral contents of different Baladi bread samples:}

Conversion of wheat into flour by milling reduces the original level of nutrients in the wheat. Therefore, the mineral content of bread varies considerably within and between different bread types depending on the flour processing extraction ratio as well as on the ingredients used in the recipe (Pomeranz, 1987, Tahvonen \& Kumpulainen, 1994). Table (5) presents the macro- (Ca, K, Na and Mg) and micro-(Fe, $\mathrm{Zn})$ mineral concentrations of bread samples. Substitution of water with either cheese whey or milk permeate increased the macro-mineral concentrations significantly $(P<0.05)$, of all bread samples compared to the control. However, bread samples contained $100 \%$ whey or permeate had higher levels $(P<0.05)$ of macro-minerals and zinc than those with $50 \%$. The $100 \%$ permeate bread had $127 \%, 183 \%, 137 \%$ and $117 \%$ more calcium, potassium, magnesium and zinc compared to the control bread sample. These results are due to the fact that dairy ingredients such as cheese whey and milk permeate are a good source of these minerals (Fitzpatrick et al., 2001, Rizk, 2016). On the other hand, substituting water with whey or permeate significantly $(P<0.05)$ decreased iron content of the resultant bread. These results are in accordance with those obtained by Bilgin et al. (2006) and Hassan et al. (2013).

\section{Texture profile analysis:}

Texture profile data of the tested flat bread samples are presented in Fig. (2) and Table (6). Hard- ness of the fresh bread sample was $1.188 \mathrm{~N}$ and it increased to $2.016 \mathrm{~N}$ after 1 day of storage. A dramatic change in the hardness values occurred after 2 and 3 days of storage, since increased to 5.5 and $6.97 \mathrm{~N}$ as a result of progress in bread staling. A further storage of bread to 5 days led to a ten-fold increase in hardness, $10.064 \mathrm{~N}$, but data are not given in the table. Replacement of dough water with 50 or $100 \%$ UF milk permeate led to a slight decrease in bread hardness overall the 3 days of storage at room temperature compared with the control sample. The effect of cheese whey replacement (50 and 100\%) showed similar behaviours to that of milk permeate.

The hardness values of bread samples with $100 \%$ replacement of milk permeate or $50 \%$ cheese whey reached approximately 50\% (3.7 and $3.47 \mathrm{~N}$, respectively) that of the control bread sample indicating the retarding effect of both milk permeate and cheese whey on the occurrence of bread staling. The adhesiveness value of the control bread sample was $0.224 \mathrm{~mJ}$ and it decreased through the 3 days of storage as a result of dryness in the bread sample. Additions of either milk permeate or cheese whey did not greatly influence the adhesiveness character of the bread samples.

The cohesiveness value of fresh control sample was 0.58 and it was slightly improved (0.64) by replacement kneading water with $100 \%$ whey. Storage of bread sample led to $19 \%$ reduction in the cohesiveness value of the control bread sample, probably as a result of staling progress in the bread samples. Additions of milk permeate or cheese whey to the dough resulted in remarkable conservation in the cohesiveness ratio, especial at the $2^{\text {ed }}$ and $3^{\text {ed }}$ days of storage (the reduction was only 11 to $13 \%$ ). The springiness of the control bread sample was $4.19 \mathrm{~mm}$ and decreased by the replacement of water with milk permeate or cheese whey. How-

Table 5: Effect of substituting water with cheese whey and UF milk permeate on mineral content of Egyptian Baladi bread

\begin{tabular}{|c|c|c|c|c|c|c|c|}
\hline \multirow{2}{*}{\multicolumn{2}{|c|}{ Samples }} & \multicolumn{6}{|c|}{ Mineral content (ppm) } \\
\hline & & $\mathbf{F e}$ & Zn & $\mathbf{C a}$ & $\mathbf{K}$ & $\mathbf{N a}$ & Mg \\
\hline & control & $11.20^{\mathrm{A}}$ & $2.787^{\mathrm{B}}$ & $93.47^{\mathrm{D}}$ & $360^{\mathrm{E}}$ & $20^{\mathrm{D}}$ & $82.23^{\mathrm{C}}$ \\
\hline \multirow[t]{2}{*}{ Permeate } & $50 \%$ & $5.135^{\mathrm{BC}}$ & $3.252^{\mathrm{B}}$ & $140.10^{\mathrm{B}}$ & $680^{\mathrm{C}}$ & $27^{\mathrm{C}}$ & $114.40^{\mathrm{B}}$ \\
\hline & $100 \%$ & $4.098^{\mathrm{C}}$ & $6.049^{\mathrm{A}}$ & $212.20^{\mathrm{A}}$ & $1020^{\mathrm{A}}$ & $80^{\mathrm{A}}$ & $195.50^{\mathrm{A}}$ \\
\hline \multirow[t]{2}{*}{ Whey } & $50 \%$ & $6.686^{\mathrm{B}}$ & $3.250^{\mathrm{B}}$ & $114.83^{\mathrm{C}}$ & $560^{\mathrm{D}}$ & $21^{\mathrm{CD}}$ & $84.62^{\mathrm{C}}$ \\
\hline & $100 \%$ & $4.782^{\mathrm{BC}}$ & $3.302^{\mathrm{B}}$ & $154.50^{\mathrm{B}}$ & $810^{\mathrm{B}}$ & $45^{\mathrm{B}}$ & $119.18^{\mathrm{B}}$ \\
\hline
\end{tabular}

$\mathrm{a}, \mathrm{b}, \mathrm{c}$ : Means with the same letter among treatments are not significantly different at $P \leq 0.05$. 
Table 6: Effect of substituting water with cheese whey or milk permeate on texture profile of Baladi bread during storage period.

\begin{tabular}{lllccccc}
\hline \multicolumn{2}{c}{ Samples } & $\begin{array}{c}\text { Hardness } \\
\left(\mathbf{N}^{*}\right)\end{array}$ & $\begin{array}{c}\text { Adhesiveness Cohesiveness } \\
(\mathbf{m J} * *)\end{array}$ & $\begin{array}{c}\text { Springiness } \\
(\mathbf{m m})\end{array}$ & $\begin{array}{c}\text { Gumminess } \\
(\mathbf{N})\end{array}$ & $\begin{array}{c}\text { Chewiness } \\
(\mathbf{m J})\end{array}$ \\
\hline \multirow{2}{*}{ Control } & & 1.188 & 0.224 & 0.58 & 4.19 & 0.690 & 2.89 \\
Permeate & $50 \%$ & 0.911 & 0.205 & 0.59 & 4.01 & 0.538 & 2.16 \\
& $100 \%$ & 0.937 & 0.158 & 0.59 & 2.65 & 0.553 & 1.46 \\
Whey & $50 \%$ & 1.469 & 0.154 & 0.58 & 2.74 & 0.848 & 2.33 \\
& $100 \%$ & 1.274 & 0.163 & 0.64 & 2.86 & 0.813 & 2.32 \\
& & & & $\mathbf{1}$ day & & & \\
Control & & 2.016 & 0.142 & 0.53 & 4.41 & 1.069 & 4.72 \\
Permeate & $50 \%$ & 1.690 & 0.212 & 0.65 & 4.37 & 1.103 & 4.82 \\
& $100 \%$ & 1.776 & 0.150 & 0.49 & 3.63 & 0.865 & 3.14 \\
Whey & $50 \%$ & 2.286 & 0.304 & 0.61 & 4.77 & 1.404 & 6.69 \\
& $100 \%$ & 1.922 & 0.192 & 0.53 & 4.27 & 1.018 & 4.35 \\
& & & & $\mathbf{2}$ day & & & \\
Control & & 5.501 & 0.202 & 0.63 & 5.56 & 3.490 & 19.41 \\
Permeate & $50 \%$ & 4.178 & 0.120 & 0.54 & 3.59 & 2.250 & 8.07 \\
& $100 \%$ & 1.896 & 0.257 & 0.53 & 4.42 & 1.014 & 4.48 \\
Whey & $50 \%$ & 3.174 & 0.201 & 0.50 & 4.46 & 1.582 & 7.06 \\
& $100 \%$ & 2.833 & 0.467 & 0.52 & 8.69 & 1.480 & 12.87 \\
& & & & $\mathbf{3}$ day & & & \\
Control & & 6.973 & 0.116 & 0.47 & 4.41 & 3.280 & 14.47 \\
Permeate & $50 \%$ & 5.272 & 0.098 & 0.39 & 3.64 & 2.044 & 7.43 \\
& $100 \%$ & 3.473 & 0.227 & 0.53 & 5.79 & 1.830 & 10.56 \\
& $50 \%$ & 3.717 & 0.160 & 0.47 & 3.00 & 1.760 & 5.27 \\
& $100 \%$ & 6.029 & 0.118 & 0.44 & 4.31 & 2.670 & 11.51 \\
\hline
\end{tabular}

*N=Newton (Force unit)

$* * \mathrm{~mJ}=$ milli Joule (Energy Unit)

ever, the springiness values were remained without remarkable change during the 3 days of storage. Gumminess and chewiness are indicators for the force and work required to bit the breads. Their values for fresh control samples were $0.69 \mathrm{~N}$ and 2.89 $\mathrm{mJ}$ respectively. All gumminess and chewiness values were progressively increased during storage and reached $3.28 \mathrm{~N}$ and $14.47 \mathrm{~mJ}$, respectively after 3 days. That means an increase of $475 \%$ to $500 \%$ in the force and work required in the human mouth to swallow the bread samples. Addition of milk permeate and cheese whey improved the gumminess and chewiness values of the fresh bread samples and reduced the losses in their characteristics during storage compared with the control samples. In conclusion, hardness, cohesiveness and chewiness

were good physical indicators for the progress of bread staling. The obtained results agree with those reported by Majzoobi et. al. (2013) as well as Hassan et. al. (2013).

\section{Freshness characteristics:}

AWRC is a simple and quick test to follow stalling of bread. Higher values of AWRC mean higher freshness of bread (Yassen et al., 2010). The changes occurring in freshness characteristics of Baladi bread stored for 1, 2 and 3 days at room temperature are shown in Table (7). The AWRC for all bread samples reduced significantly $(P<0.05)$ during storage. It could be observed that replacing mixing water by $50 \%$ UF milk permeate or cheese whey affect reduction in WARC to 233, 215 and 

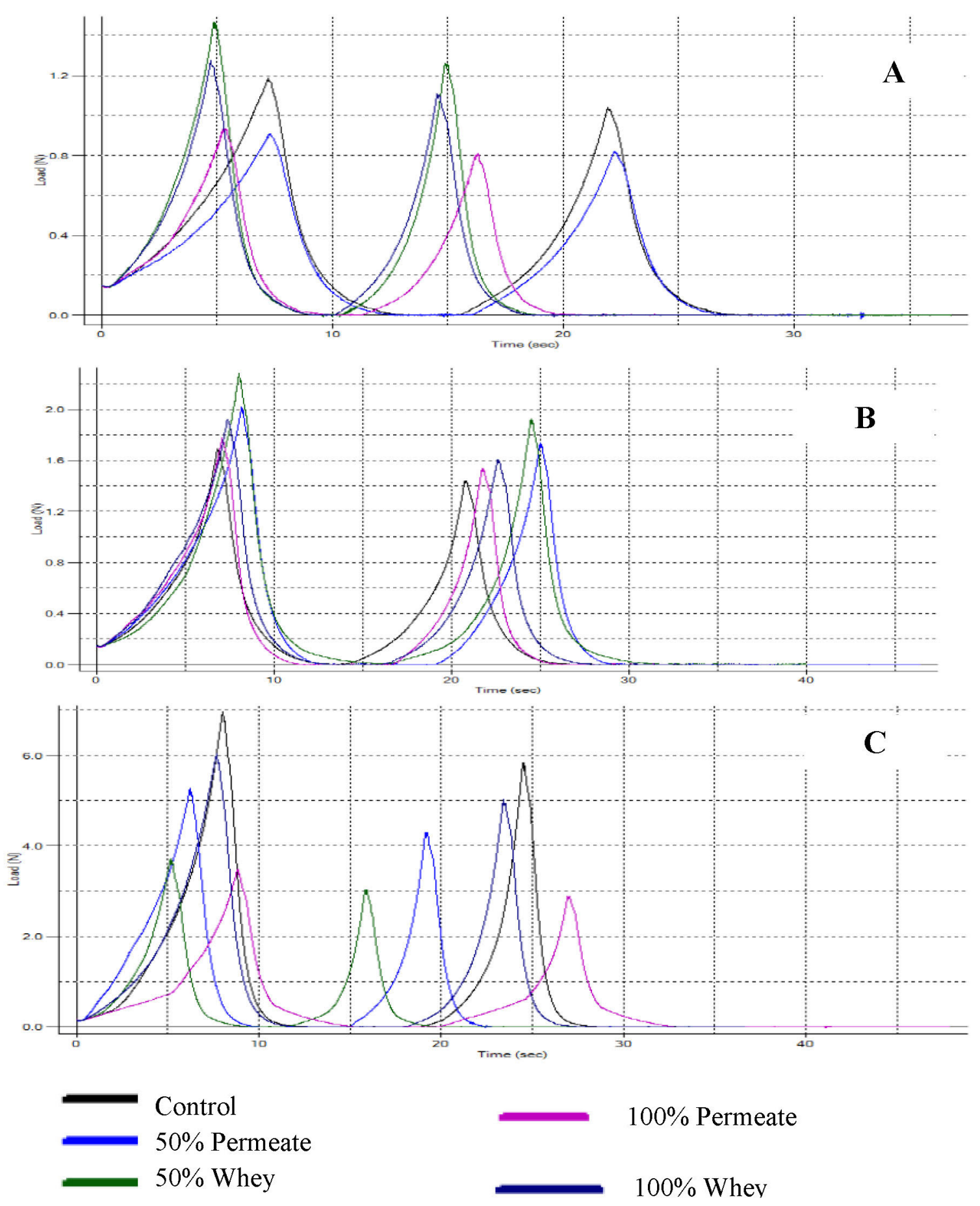

Fig. 2: Texture profile graphs of Baladi bread containing different ratios of cheese whey or milk permeate during storage period

(A): Fresh bread samples, (B): bread samples after 1 day of storage, and

(C): bread samples after 3 days of storage.

$211 \%$ and $248,213,205 \%$ at 1,2 and 3 days compared to 270,254 and $222 \%$ for the control. On the other side complete replacing of water by whey and permeate improved significantly $(P<0.05)$ WARC to 240 and 241 , respectively compared with $50 \%$ replacing after 3 days storage. Zadow \& Hardham
(1981) reported that the breads with added whey were perceived by panelists to stay fresh longer than the control. Yousif et al. (1998) observed that use of concentrated whey retarded staling and improved the keeping quality of French-type bread. 
Table 7: Effect of substituting water with milk whey and permeate on freshness of Baladi bread during storage period

\begin{tabular}{lllllc}
\hline & \multicolumn{3}{c}{ Samples } & \multicolumn{4}{c}{$\%$ AWRC } \\
\cline { 3 - 6 } & & Zero time & $\mathbf{1}$ day & $\mathbf{2}$ days & $\mathbf{3}$ days \\
\hline control & & $323.87^{\mathrm{Aa}}$ & $270.00^{\mathrm{ABb}}$ & $254.51^{\mathrm{ABb}}$ & $222.33^{\mathrm{ABc}}$ \\
Permeate & $50 \%$ & $241.69^{\mathrm{Ba}}$ & $233.29^{\mathrm{Bb}}$ & $215.53^{\mathrm{Cc}}$ & $211.06^{\mathrm{Bc}}$ \\
& $100 \%$ & $288.55^{\mathrm{Aa}}$ & $284.50^{\mathrm{Aa}}$ & $282.09^{\mathrm{Aa}}$ & $241.67^{\mathrm{Ab}}$ \\
Whey & $50 \%$ & $289.18^{\mathrm{Aa}}$ & $248.77^{\mathrm{ABb}}$ & $213.05^{\mathrm{Cc}}$ & $205.83^{\mathrm{Bc}}$ \\
& $100 \%$ & $282.54^{\mathrm{Aa}}$ & $277.72^{\mathrm{Aab}}$ & $238.48^{\mathrm{BCb}}$ & $240.73^{\mathrm{Ab}}$ \\
\hline
\end{tabular}

A, B, C: Means with the same letter among treatments in the same storage period are not significantly different $(P \leq 0.05)$. a, b, c : Means with the same letter for same treatment during storage periods are not significantly different $(P \leq 0.05)$.

\section{Sensory properties of Baladi bread:}

As shown in Table (8) and Fig. (3), substitution of water with cheese whey or milk permeate in Baladi bread formula significantly improved the Baladi bread appearance score and this was more remarkable for samples made with $100 \%$ whey or permeate. Also, colours of crust were significantly improved at $100 \%$ of whey or permeate. However, the $50 \%$ replacement water with whey or permeate did not significantly improve the colour of crust. This might be due to the high lactose content in whey which enhances the Maillard reaction of the crust colour. Significant improvements in taste and odour properties were observed with 100 and 50\% substitution the water with whey and permeate, respectively. The highest scores for roundness and crumb distribution were noted in bread sample containing $100 \%$ milk permeate. Substitution of water with whey or permeate in Baladi bread formula significantly increased the score for separation of layer compared to the control (100\% water). Our results refer that whey or permeate at $100 \%$ substitution is most effective in increasing the separation of layer. This could be due to lactose and lactic acid fermentation which may stimulate the gas formation during dough proofing. Baladi bread lower and upper layer thickness scores were improved as a result of whey or permeate substitution, but the $100 \%$ permeate was more effective in this respect. Our results agree with Al-Eid et. al. (1999) who found that, substituting water with UFMP had significant effect on sensory properties and baking quality of white pan bread. Burrington (1999) and Stoliar (2009), stated that, lactose content in whey and permeate is often used to enhance the Maillard reaction, improves emulsification and crumb structure, and enhances the flavour in baking, confectionery and pastry.

Therefore, it could be stated that, $100 \%$ substitution of water with whey or permeate in Baladi bread formula could enhance the sensory properties in resultant product. These may be due to the lactose, mineral and some protein contents in whey and permeate, which may play an important role in enhancement the sensory properties in Baladi bread. These results agree with Khider et. al.

Table 8: Sensory evaluation of Baladi bread prepared with cheese whey or milk permeate as water substitute

\begin{tabular}{|c|c|c|c|c|c|c|c|c|c|c|}
\hline \multicolumn{2}{|c|}{ Sample } & \multicolumn{9}{|c|}{ Properties } \\
\hline & & $\begin{array}{l}\text { Appear- } \\
\text { ance }\end{array}$ & $\begin{array}{c}\text { colour of } \\
\text { crust }\end{array}$ & Taste & odour & $\begin{array}{c}\text { Round- } \\
\text { ness }\end{array}$ & $\begin{array}{c}\text { crumb } \\
\text { distribu- } \\
\text { tion }\end{array}$ & $\begin{array}{c}\text { separation } \\
\text { layer }\end{array}$ & $\begin{array}{c}\text { upper } \\
\text { layer } \\
\text { thickness }\end{array}$ & $\begin{array}{c}\text { lower } \\
\text { layer } \\
\text { thickness }\end{array}$ \\
\hline \multicolumn{2}{|l|}{ Control } & $6.8^{b}$ & $7.5^{b}$ & $6.8^{b}$ & $7.0^{\mathrm{b}}$ & $7.3^{b}$ & $7.3^{\mathrm{b}}$ & $8.2^{\mathrm{a}}$ & $6.7^{c}$ & $7.0^{\mathrm{b}}$ \\
\hline \multirow[t]{2}{*}{ Permeate } & $50 \%$ & $7.8^{\mathrm{ab}}$ & $7.5^{\mathrm{b}}$ & $7.3^{\mathrm{b}}$ & $7.0^{\mathrm{b}}$ & $8.5^{\mathrm{a}}$ & $7.7^{\mathrm{ab}}$ & $8.8^{\mathrm{a}}$ & $7.5^{\mathrm{bc}}$ & $7.3^{b}$ \\
\hline & $100 \%$ & $8.8^{\mathrm{a}}$ & $7.9^{\mathrm{ab}}$ & $8.3^{\mathrm{a}}$ & $8.3^{\mathrm{a}}$ & $9.0^{\mathrm{a}}$ & $8.7^{\mathrm{a}}$ & $9.3^{\mathrm{a}}$ & $8.8^{\mathrm{a}}$ & $9.0^{\mathrm{a}}$ \\
\hline \multirow[t]{2}{*}{ Whey } & $50 \%$ & $7.2^{\mathrm{b}}$ & $7.5^{\mathrm{b}}$ & $7.7 \mathrm{~b}$ & $7.8^{\mathrm{ab}}$ & $8.5^{\mathrm{a}}$ & $7.5^{\mathrm{b}}$ & $8.7^{\mathrm{a}}$ & $8.2^{\mathrm{ab}}$ & $8.0^{\mathrm{ab}}$ \\
\hline & $100 \%$ & $8.2^{\mathrm{a}}$ & $8.3^{\mathrm{a}}$ & $8.3^{\mathrm{a}}$ & $8.2^{\mathrm{a}}$ & $8.4^{\mathrm{a}}$ & $8.5^{\mathrm{a}}$ & $9.2^{\mathrm{a}}$ & $8.3^{\mathrm{ab}}$ & $8.8^{\mathrm{a}}$ \\
\hline
\end{tabular}

a, b, c: Means with same letter among treatments are not significantly different at $(P \leq 0.05)$. 


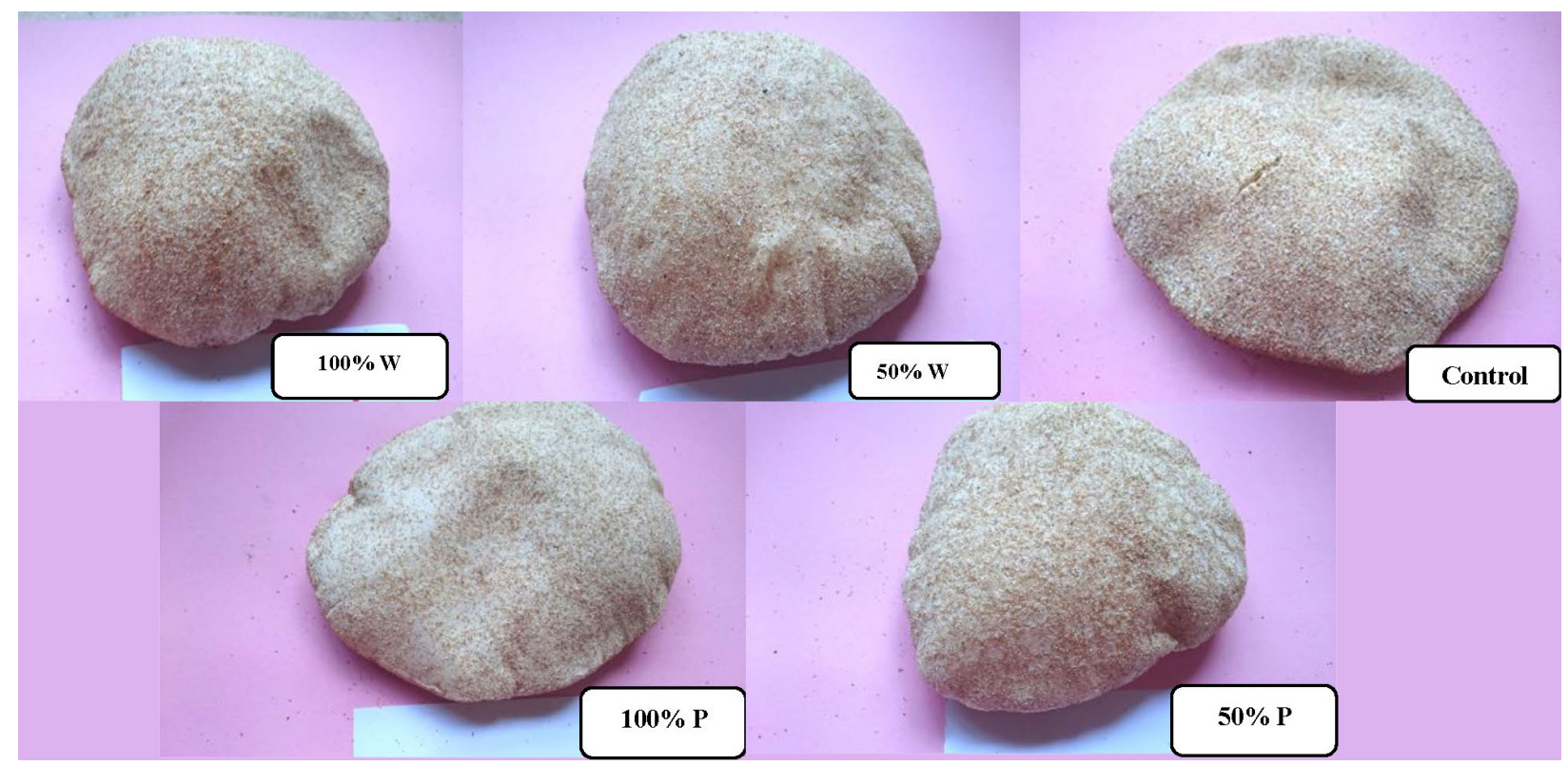

Fig. 3: Baladi bread samples fortified with different ratios of cheese whey $(W)$ and UF milk permeate $(P)$ as water substitute

(2015) who recommended that, supplementation of pan bread with fresh and fermented permeate improved the quality and significantly increased the nutritive value of the bread via protein and mineral contents and extended the shelf-life of pan bread.

Finally, it could be concluded that, Egyptian Baladi bread can be made by adding cheese whey or milk permeate in substution of added water. Fortification of Baladi bread with cheese whey or milk permeate enhanced the quality attributes, and nutritional value of bread.

\section{REFERENCES}

AACC. 2000. Approved methods of American association of cereal chemists (10 $10^{\text {th }}$ ed.). St Paul: American Association of Cereal Chemists, Inc.

Al-Eid S. M., A. A. Al-Neshawy \& S. S. Al-Shaikh Ahmad 1999. Influence of substituting water with ultrafiltered milk permeate on dough properties and baking quality of white pan bread. Journal of Cereal Science, 30: 79-82.

Anderssen R.S., F. Bekes, P.W.Gras, A. Nikolov \& J.T. Wood 2004. Wheat flour dough extensibility as a discriminator for wheat varieties. Journal of Cereal Science, 39: 195-203.

Anton A.A., Ross K.A., Lukow O.M.R., Gary Fulcher \& Arntfield S.D. 2008. Influence of added bean flour (Phaseolus vulgaris L.) on some physical and nutritional properties of wheat Flour tortillas. Food Chemistry, 109: 33-41.

AOAC 2012. Official Methods of Analysis. $18^{\text {th }}$ edition AOAC International Gaithersburg, MD. no. (9685-080), a nd CH. 4, P. 56-57 and no. (985.01) ch.3, p.6.

Baldasso, C., Barros T.C. \& Tessaro I.C. 2011. Concentration and purification of whey proteins by ultrafiltration. Desalination, 278: 381-386.

Bilgin, B., Daglioglu O. \& Konyali, M. 2006. Functionality of bread made with pasteurized whey and/or buttermilk. Italian Journal of Food Science, 18: 277-286.

Burrington K. 1999. Whey products in baked goods. U.S. Dairy Export Council, Applications Monographs. Bakery, pp: 1-8.

Carvalho F., Prazeres A.R. \& Rivas J. 2013. Cheese whey wastewater: Characterization and treatment. Science of the Total Environment, 445-446: 385-396.

Davidou, S., M. Le Meste, E. Debever \& D. Bekaert, 1996. A contribution to the study of staling of white bread: effect of water and hydrocolloid. Food Hydrocolloids, 104: 375383.

Divya N. \& Rao K.J. 2010. Studies on utilization of Indian cottage cheese whey in wheat bread manufacture. Journal of Food Processing and Preservation, 34: 975-992. 
Drokan B., Primorac L., Erk Z., Pavlaic Z. \& Mandic M.L. 2003. Influence of whey on volume and porosity of wheat bread. $4^{\text {th }}$ Int. Congress of Cereal Technologists, Opatija, Croatia.

El-Farra A.A., Korshid A.M., Mansour S.M. \& Galal A.M. 1982. Studies on the possibility of supplementation of Baladi bread with various commercial soy products. 1 ${ }^{\text {st, Egypt. }}$ Conf. on Bread Res. 9-11 Nove., Giza, A.R.E.

Erdogdu-Arnoczky N., Czuchajowska Z. \& Pomeranz Y. 1996. Functionality of whey and casein in fermentation and in bread baking by fixed and optimized procedures. Cereal Chemistry, 73: 309-316.

Fitzpatrick, J.J., M. I. Ahrens \& S. W. Smith, 2001. Effect of manganese on lactobacillus casei fermentation to produce lactic acid from whey permeate. Process Biochemistry 367:671-675.

Gelinas, P., Audet, J., Lachance, O. \& Vachan, M. 1995. Fermented dairy ingredients for bread. Effects on dough rheology and bread characteristics. Cereal Chemistry, 72: 151-154.

Hallén E., İbanoğlu S. \& Ainsworth P. 2004. Effect of fermented/germinated cowpea flour addition on the rheological and baking properties of wheat flour. Journal Food Engineering, 63: 177-184.

Hassan Amal A., Hoida El-Shazly, Sakr Amany M. \& Waheed A.R. 2013. Influence of substituting water with fermented skim milk, acid cheese whey or buttermilk on dough properties and baking quality of Pan bread. World Journal of Dairy and Food Sciences, 8: 100117.

Jelen P. \& Tossavainen, O. 2003. Low lactose and lactose-free milk and dairy products: Prospects, technologies and applications. Australian Journal of Dairy Technology: 58, 161-165.

Jooyandeh H. 2006. Quality improvement of Iranian Lavash bread $18^{\text {th }}$ Indian convention of Food Scientists and Technologists, Hyderabad, India. p. 80.

Jooyandeh H., Minhas K.S. \& Amarjit K. 2009. Sensory quality and chemical composition of wheat breads supplemented with fermented whey protein concentrate and whey permeate. Journal of Food Science and Technology,46: 146-148.
Khider, M., Elbanna K., Seoudi O. \& El-Fakharany A. 2015. Lactic acid fermented permeates and mushroom powder (Pleurotus ostreatus Hk 35) for improvement of the nutritional value and quality of Pan bread. International Journal o Current Microbiology and Applied Sciences, 4: 723-736.

Kitterman, J.S. \& Rubenthaler G.L. 1971. Assessing the quality of early generation wheat selection with the micro AWRC test. Cereal Science Today, 16: 313-316.

Ling E.R. 1963. A Text Book of Dairy Chemistry $3^{\text {rd }}$ Ed. Vol. 2. practical,.76 -98. Chapman and Hall. Ltd London, UK.

Majzoobi M., Farahnaky A., Nematdahi Z., Mohammad M. \& Ardakani M. 2013. Effect of different levels and particle sizes of wheat bran on the quality of flat bread. Journal of Agriculture Science and Technology, 15: $115-123$.

Marhamatizadeh M.H., Ehsandoost E., Gholami P., Moshiri H. \& Nazemi M. 2012. Effect of permeate on growth and survival of Lactobacillus acidophilus and Bifidobacterium bifidum for production of probiotic nutritive beverages. World Applied Sciences Journal, 18: 1389-1393.

Marshall V.M., Cole W.M. \& Mabbit L.A. 1982. Fermentation of specially formulated milk with single strains of bifidobacteria. Journal of the Society of Dairy Technology, 35: 143144.

Metcalf X. \& Eddy X. 2003. Wastewater Engineering: Treatment and Reuse. In: Wastewater Engineering, Treatment, Disposal and Reuse. Techobanoglous, G.: Burton, F.L. \& Stensel, H.D. (eds), Tata McGraw-Hill Publishing Company Limited, 4th edition. New Delhi, India.

Morr C.V. 1989. Beneficial and adverse effects of water-protein interactions in selected dairy products. Journal of Dairy Science, 72: 757580.

Motrena S.G., Carvalho M.J., Canada J., Alvarenga N.B., Lidon F.C. \& Elisa B.P. 2011. Characterization of gluten-free bread prepared from maize, rice and tapioca flours using the hydrocolloid seaweed agar-agar. Recent Research in Science and Technology, 3: 64-68. 
Mousa E.I., Ibrahim R.H., Shuey W.C. \& Maneval R.D. 1979. Influence of wheat classes, flour extraction, and baking methods on Egyptian Baladi bread. Cereal Chemistry: 56, 563-566.

Murad H.A., Refaea R.I. \& Aly E.M. 2011. Utilization of UF-permeate for production of $\beta$-galactosidase by lactic acid bacteria. Polish Journal of Microbiology, 60: 139-144.

Onwulata C.I. \& Huth P.J. 2008. Whey Processing - Functionality and Health Benefits, Vol. 1 Ames, IA: Wiley-Blackwell.

Pomeranz, Y. 1987. Modern Cereal Science and Technology. P.220 Vch Pub. Inc. New York.

Rantamaki P., Tossavainen O., Outinen M., Tupasel T. \& Koskinen P. 2006. Food applications of the whey protein fractions produced in pilot scale processes. I. Bread. Milchwissenschaft, 61: 65-68.

Renner E. \& Abd El-Salam 1991. Application of ultrafiltration in the dairy industry. Elsevier Applied Science. London, New york. pp. 158-161.

Riera-Rodriguez F. 2002. Functional properties of milk proteins. Alimentacion - Equipos-y Tecnologia., 21: 43-53.

Rizk, Ayat E. 2016. Study of production functional beverages of milk permeate fortified with fruit and herbs. Middle East Journal of Applied Sciences, 06 01: 155-161.

Román G.y., Vatai A., Ittzés Z., Kovács A. \& Czermak P. 2012. Modeling of diafiltration processes for demineralization of acid whey: an empirical approach. Journal of Food Process Engineering, 35: 708-714.

SAS Institute 1999. Statistical Analysis system. SAS user's guide: for personal computers, version 8.2 Edition SAS Instintute, Cary, N.C.
Sharadanant R. \& Khan K. 2003. Effect of hydrophilic gums on frozen. dough. II. Bread characteristics. Cereal Chemistry, 80: 773-80.

Spalatelu C. 2012. Biotechnological valorization of whey. Review Article. Innovative Romanian Food Biotechnology, 10: 1-8.

Stoliar M. 2009. Whey ingredients in bakery products. U.S. Dairy Export Council, Applications Monographs. Bakery, pp: 1-8.

Tahvonen, R. and Kumpulainen J. 1994. Levels of selected elements in Finnish breads. Journal of Food Composition and Analysis, 71-2: 83-93.

Udovicic D.D.I., Milanovic S.D. \& Ilicic M.D. 2013. Permeate components valorization for beverage manufacturing-permeate based beverage production with or without lactose hydrolysis. Agro Food Industry Hi Tech., 24: 24-27.

Volpe T., \& Zabik M.E. 1975. A whey protein contributing to loaf volume depression. Cereal Chemistry, 52: 188-197.

Yamazaki W.T. 1953. An alkaline water retention capacity test for the evaluation of cookie baking potentialities of soft winter wheat flour. Cereal Chemistry, 30: 242-249.

Yassen, A.A., Shouk, A. \& Ramadan, M.T. 2010. Corn-wheat pan bread quality as affected by hydrocolloids. Journal of American Science, 6: $684-690$.

Yousif A.K., Abeu-Eishan M.A., Humaid M.A. \& Al-Tabba M.J. 1998. Concentration of acidic whey and its functionality in French type bread. International Journal of Dairy Technology, 51: 72-76.

Zadow J.G. \& Hardham J.F. 1981. Studies on the use of whey protein concentrates in bread. Aust. Australian Journal of Dairy Technology, 36: 60-63. 


\section{الاستفادة من شرش الجبن وراشح اللبن يِّ تصنيع الخبز البلدي}

\section{أسامة ابراهيه البطاوي ، سهر محمد مهلي، محمدل يوسف ابو النجا}

قسم علوم الأغذية - كلية الزراعة - جامعة عين شمس - شبر ا الخيمة - اگr|| - القاهرة - مصر

يهدف البحث الى دراسة تأثير إستخدام شرش الجبن أو راشح اللبن كبديل للماء أثناء صناعة الخبز البلدي على خواص الخبز الناتج. حيث تم تصنيع اربع معاملات من الخبز البلدي وذلك باستبدال الماء المضاف أثناء أثناء

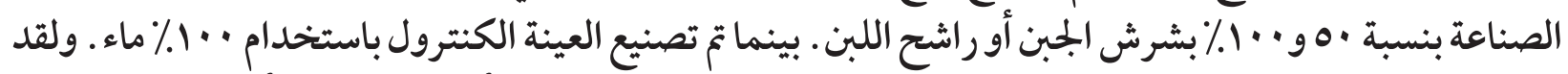

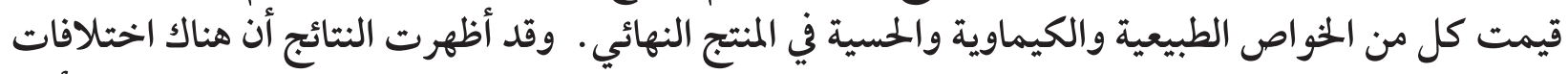

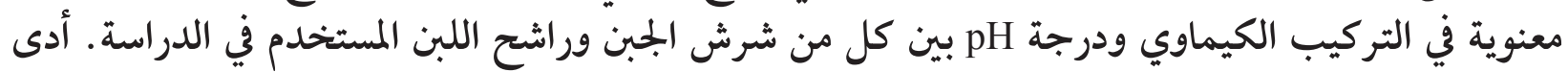

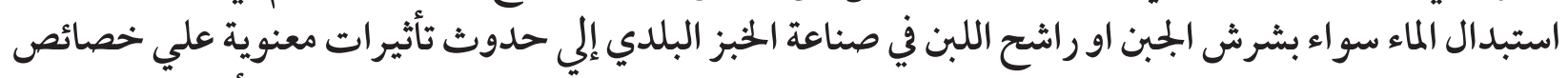

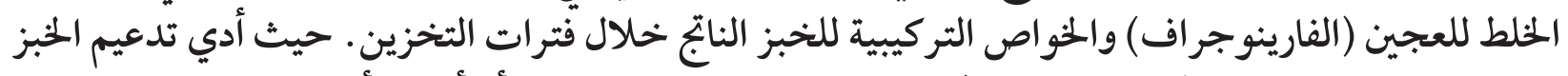

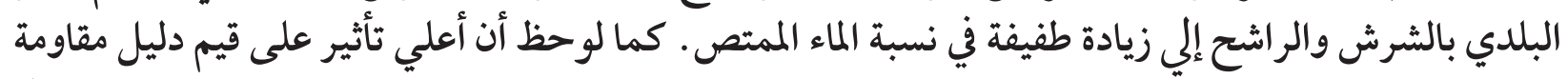

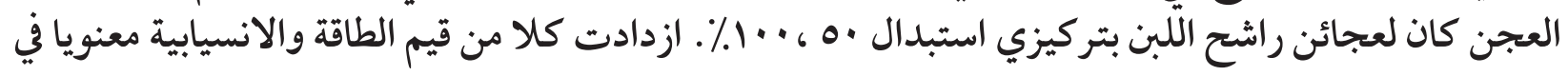

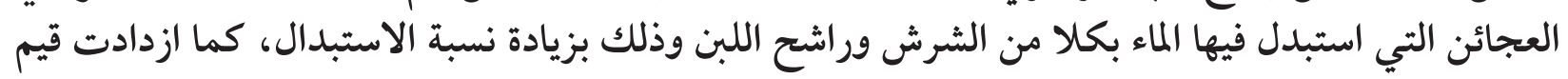

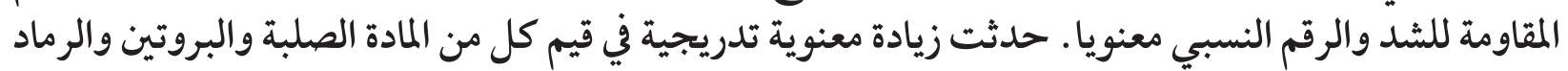

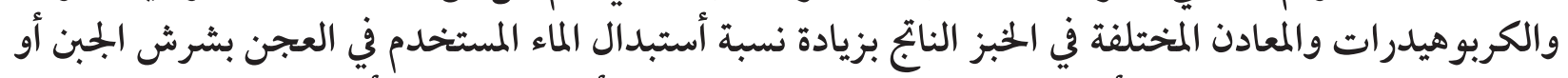

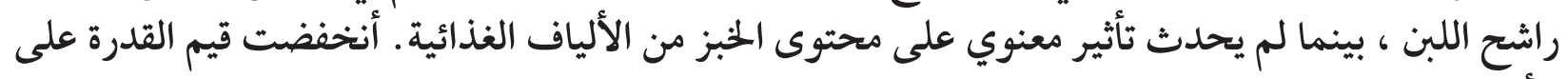

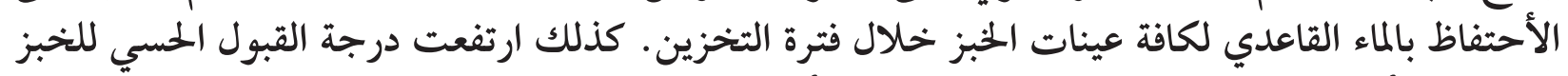

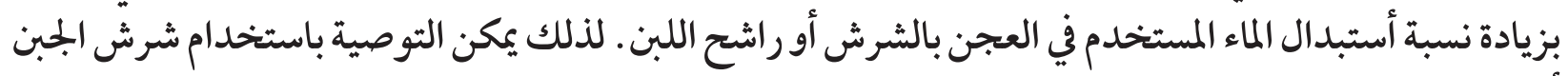
أو راشح اللبن كبديل للماء المستخدم في صناعة الخبز البلدي حيث يؤدي استخدامه الى تحسين القيمة الغذائية والوظيفية وكذلك الخو اص الحسية للمنتج النهائي. 